\title{
Analysis of the Application of Regulatory Dendritic Cells in Kidney Transplantation
}

\author{
Haiyan Xu and Xiaozhou He* \\ Department of Urology, Third Affiliated Hospital of Soochow University, China
} *Corresponding author: Xiaozhou He, Department of Urology, Third Affiliated
Hospital of Soochow University, No.185, Juqian Street, Changzhou 213003, China.
Received Date: February 09,2020

Published Date: February 25,2020

\begin{abstract}
Kidney transplantation $\left(\mathrm{KT}_{\mathrm{x}}\right)$ is the optimum therapy for end-stage renal diseases. However, long-term usage of immunosuppressive agents results in various toxicities and side effects, which has been a major obstacle for recipients. How to reduce the dosages of immunosuppressive agents has become a problem that desperately needs to be solved. Among potential methods, cell therapy has great potential, and regulatory dendritic cells (DC ) have attracted special attention for their tolerogenic ability. Currently, some DC-based clinical trials are ongoing or have been completed at several research centers, including an immune tolerance trial in $\mathrm{KT}_{\mathrm{x}}$ named "The One Study", in which autologous peripheral blood mononuclear cells were isolated and stimulated with low doses of GM-CSF or immunosuppressive agents. DC ${ }_{\text {reg }}$ generated with different induction methods or from different cell sources may function in different ways in different organs. After surgery, kidney allografts become the focus of attacks by the immune system and form a specific immune microenvironment. Can $\mathrm{DC}_{\mathrm{reg}}$ successfully induce immune tolerance in $\mathrm{KT}_{\mathrm{x}}$ recipients? In the present manuscript, we comprehensively analyzed the potential of $\mathrm{DC}_{\mathrm{reg}}$ in $\mathrm{KT}_{\mathrm{x}}$ from the perspective of kidney immunology.
\end{abstract}

Keywords: Regulatory dendritic cells (DCreg); Kidney transplantation; Cell therapy

Abbreviations: DCs: Dendritic Cells; DCreg: Regulatory Dendritic Cells; KTx: Kidney Transplantation; HLA-G: Human Leukocyte Differentiation Antigen; PD-L: Programmed Death-Ligand; mDCs: Myeloid DCs; PDCs: Plasmacytoid DCs

\section{Introduction}

After kidney transplantation $\left(\mathrm{KT}_{\mathrm{x}}\right)$, recipients need to take immunosuppressive agents to prevent rejection. However, the toxicities and side effects of long-term usage of immunosuppressive agents should not be overlooked. How to reduce the dosages of immunoinhibitory agents has become a major problem that desperately needs to be solved. Currently, new immunosuppressive strategies, new immunosuppressive reagents and cell therapies are all being researched and developed [1]. Cell therapy has drawn increasing attention, and further investigation will not only provide potential targets of immunosuppressive reagents but also have very important clinical value. Dendritic cells $\left(D_{s}\right)$ are heterogenous professional antigen-presenting cells that play central roles in innate immunity and adoptive immunity, including roles in immune tolerance induction and immune stabilization [2]. A group of DCs with the capability of immune tolerance induction was named tolerogenic $\mathrm{DC}_{\mathrm{s}}[3]$ or regulatory $\mathrm{DC}_{\mathrm{s}}\left(\mathrm{DC}_{\text {reg }}\right) . \mathrm{DC}_{\text {reg }}$ have been applied as a cell therapy-based alternative to immunosuppressive agents. In addition, phase II clinical trials assessing the treatment of diabetes and autoimmune diseases with $\mathrm{DC}_{\text {reg }}$ have been carried out [4]. The kidneys, which have a special structure and function, are an important organ for ensuring a stable internal environment and normal metabolism. Before and after $\mathrm{KT}_{\mathrm{x}}$, does $\mathrm{DC}_{\text {reg }}$ infusion function to induce immune tolerance as expected? This is the focus of $\mathrm{DC}_{\text {reg }}$-based cell therapy. In this manuscript, we review the application of $\mathrm{DC}_{\text {reg }}$ in $\mathrm{KT}_{\mathrm{x}}$ recipients in regard to kidney immunology.

\section{Discussion}

\section{Characteristics of $\mathrm{DC}_{\text {reg }}$}

There are few natural $\mathrm{DC}_{\text {reg }}$ in vivo, and these cells are small and round [5] and greatly differ from $\mathrm{DC}_{\text {reg }}$ obtained in vitro. $\mathrm{DC}_{\text {reg }}$ induced in vitro are always smaller than normal mature DCs, with few short 
dendrites, and $\mathrm{DC}_{\text {reg }}$ cell phenotypes are also different from mature DC phenotypes [6]. Without inflammatory stimulation, immature $\mathrm{DC}_{\mathrm{s}}$ participate in peripheral immune tolerance induction, showing a $\mathrm{DC}_{\text {reg }}$ phenotype and functional characteristics. Under normal conditions, $\mathrm{DC}_{\text {reg }}$ express low levels of major histocompatibility complex II molecules and costimulatory molecules such as CD80 and CD86 [7]. Nevertheless, the expression of inhibitory molecules, such as human leukocyte differentiation antigen-G (HLA-G) [8], programmed death-ligand (PD-L)-1 and 2 [9], and galectin [10], increases. An increased PD-L1/CD86 ratio and enhanced IL-10 secretion are thought to be characteristics of $\mathrm{DC}_{\text {reg }}[11] . \mathrm{DC}_{\text {reg }}$ may have relatively specific phenotypes in different tissues and organs; for instance, $\mathrm{DC}_{\text {reg }}$ are likely to have a CD141+CD14+ phenotype in the skin [12], and DCreg may be DC-10 in the blood [13,14]. At present, genetic modification, drug intervention, cytokine exposure and so on are used to induce $\mathrm{DC}_{\text {reg }}$ and precursor cells can be isolated from bone marrow cells, peripheral blood mononuclear cells or lymph node cells [15-17]. $\mathrm{DC}_{\mathrm{reg}}$ can produce TGF- $\beta 1$ [18,19], IL-10 [20,21], 2,3-IDO [22-24], IFN- $\gamma$ and the Epstein-Barr virus (EBV) induction gene [25] or induce regulatory $\mathrm{T}$ cells (Tregs) $[26,27]$ to exert their immune tolerance induction function.

\section{Effects of the internal environment on DCs in $\mathrm{KT}_{\mathrm{x}}$ recipients}

Under normal conditions, $\mathrm{KT}_{\mathrm{x}}$ recipients receive immune induction therapy before surgery and routine immunosuppressant administration after surgery to suppress potential immune rejection. Specific and nonspecific immunosuppressants severely weaken recipient immune function, and $\mathrm{DC}_{\mathrm{s}}$ are significantly affected. Studies have shown that immunosuppressive agents have different effects on different DC subsets. After $\mathrm{KT}_{\mathrm{x}}$, the numbers of recipient myeloid $\mathrm{DC}_{\mathrm{s}}\left(\mathrm{mDC}_{\mathrm{s}}\right)$ and plasmacytoid $\mathrm{DC}$ (pDCs) are dramatically decreased, and the number of $\mathrm{mDC}_{s}$ does not recover within 3 months after surgery [28]. If recipients receive immunosuppressive therapy in addition to conventional immunosuppressive therapy, DC numbers, including the numbers of $\mathrm{mDC}_{\mathrm{s}}$ and $\mathrm{pDC}_{\mathrm{s}^{\prime}}$ decline more significantly early post operation; CD62L expression significantly increases on $\mathrm{mDC}_{\mathrm{s}^{\prime}}$ but CD86 expression significantly decreases [29]. CD62L, an adhesion molecule, can mediate the initial retention related to DC rolling on endothelial cells. If recipients have taken immunosuppressive agents for over 1 year, the number of peripheral blood $\mathrm{DC}_{\mathrm{s}}(\mathrm{mDC} 1, \mathrm{mDC} 2$ and $\mathrm{pDC}_{\mathrm{s}}$ ) is decreased [30,31]. In other words, immunosuppressive agents result in maturation arrest in peripheral $\mathrm{m} \mathrm{DC}_{\mathrm{s}}$ [32]. Some studies have reported that $\mathrm{DC}_{\text {reg }}$ numbers increase after usage of immunosuppressive agents. Rapamycin application can induce the production of ILT3highILT4high $\mathrm{DC}_{\mathrm{s}}$ [33], which have the ability to induce immune tolerance. Specific anti-CD52 monoclonal antibody (alemtuzumab, also called Campath-1H) induction therapy dramatically decreases the number of peripheral blood $\mathrm{DC}_{\mathrm{s}^{\prime}}$ and after one month, $\mathrm{mDC}_{\mathrm{s}}$ will transform into $\mathrm{pDC}_{\mathrm{s}}$ (the $\mathrm{mDC}_{\mathrm{s}} / \mathrm{pDC} \mathrm{s}_{\mathrm{s}}$ ratio declines) [34]. CTLA-4-Ig (belatacept) application can induce $\mathrm{DC}_{\mathrm{s}}$ to express HLA-G [35], which interferes with the activation of $\mathrm{T}$ cells. In recipients treated with belatacept, the numbers of regulatory cells (Tregs/regulatory B cells (Bregs)/plasmacytoid dendritic cells $\left(\mathrm{pDC}_{\mathrm{s}}\right)$ ) markedly increase in renal allograft tissues, but the proportions of apoptotic cells and aged cells significantly decrease, and proliferation marker expression increases [36]. All of the published research indicates that immunosuppressive agents can interfere with DC growth and differentiation or the induction of $\mathrm{DC}_{\text {reg }}$ and the results also emphasize the key role of $\mathrm{DC}_{\text {reg }}$ in inhibiting alloantigen-mediated rejection. The effects of different immunosuppressive agents may overlap. Thus, the following aspects, including $\mathrm{DC}_{\text {reg }}$ preparation, infusion frequency, pathways and cell numbers, all need to be considered to evaluate the similar and unique effects of immunosuppressive agents when $\mathrm{DC}_{\text {reg }}$ are applied as a cell therapy.

\section{Specific microenvironment of renal allograft tissue}

CX3CR1 $+\mathrm{DC}_{\mathrm{s}}$ can be found in the renal mesenchyme and glomerular mesangium by confocal laser scanning microscopy. These $\mathrm{DC}_{\mathrm{s}}$ highly express CD11c, F4/80, MHCII, FcR and inhibitory costimulatory molecules. Among these cells, at least one subgroup has the ability to perform phagocytosis, which means that the cells in this subgroup are tissue-resident immature $\mathrm{DC}_{\mathrm{s}^{\prime}}$ and this subgroup forms a monitoring network for the microenvironment [37]. During the process of removal from the donor, transfer into an organ-preservation fluid, and implantation into the recipient, a renal allograft will undergo ischemia-reperfusion injury, which causes the release of endogenous molecules. Pattern recognition receptors can recognize these molecules as danger signals and induce inflammatory cell recruitment and mediator activation. As one of the sentinels in the kidneys, $\mathrm{DC}_{\mathrm{s}}$ will mature in the microenvironment and drain into the lymph nodes, presenting and activating $\mathrm{T}$ cells. Under this condition, $\mathrm{T}$ cells can differentiate into Th1 and Th17 effector cells or Th2 cells and Tregs [38,39]. Animal experiment results suggest that donor $\mathrm{DC}_{\mathrm{s}}$ in renal allograft tissue are rapidly replaced by recipient $\mathrm{DC}_{s}$ after the donor kidney is implanted into the recipient [40]. Infiltrated recipient $\mathrm{DC}_{\mathrm{s}}$ and $\mathrm{T}$ cells in tissues are associated with shortened graft survival [41]. Clearance of recipient $\mathrm{DC}_{\mathrm{s}}$ can reduce the proliferation and survival of infiltrating T cells in a graft and inhibit effector T cell-mediated rejection [40,42]. Renal tubular epithelial cells are thought to be the main cell type that attracts white blood cells during the inflammatory response in the kidneys. They release MIP3 $\alpha /$ CCL20, attracting immature DCs [43]. Renal tubular epithelial cells produce GM-CSF, inducing $\mathrm{pDC}_{\mathrm{s}}$ to perform phagocytosis and enhancing the alloantigen responsiveness of CD4+ and CD8+ T cells, which may act in the indirect alloantigen-presentation process [44]. Studies also showed the importance of $\mathrm{pDC}_{\mathrm{s}}$ in the induction of tolerance via the special mechanisms [45]. A recent study indicated that Tregs could also induce $\mathrm{DC}_{\text {reg }}$ generation, which was probably due to the contents of extracellular vesicles (such as miR-150-5p and miR-142-3p) released by Tregs, and that these $\mathrm{DC}_{\text {reg }}$ could secrete increased amounts of IL-10 and decreased amounts of IL- 6 when stimulated with LPS [46]. 
The renal parenchyma consists of the renal cortex and medulla. The renal cortex is rich in blood vessels, and the renal medulla shows a significant osmotic gradient. Microarray analysis suggested that the hypertonic environment of the renal medulla could induce medulla $\mathrm{DC}_{\mathrm{s}}$ to dramatically increase the expression of transcripts with anti-inflammatory functions while reducing the expression of alloantigen-recognition transcripts, reducing the risk of local alloantigen rejection. The results indicated that the renal medulla environment might inhibit alloantigen responsiveness by regulating $\mathrm{DC}_{\mathrm{s}}[47,48]$. Study results for a large-sample phenotypic detection and transcriptomic analysis of three kinds of DC (mDC1, mDC2, and pDC) from mice and humans showed that the functions of DC subtypes from different lymphatic hematopoietic systems due to the cell origin rather than the microenvironment. In comparison, DC subtypes from human lungs and skin were affected by the tissue microenvironment [49]. Currently, no reports on the origin of renal $\mathrm{DC}_{\mathrm{s}}$ have been published, but renal $\mathrm{DC}_{\mathrm{s}}$ perhaps have relatively special phenotypes and functions in inflammatory responses and noninflamed tissue. After infusion into recipients, the ideal prognosis for $\mathrm{DC}_{\mathrm{reg}}$ is the following progression: binding to endothelial cells, infiltrating allograft tissues, migrating into lymphatic vessels, traveling to secondary or primary lymphoid organs, and inducing alloantigen-responsive $\mathrm{T}$ cell apoptosis, clonal deletion or Treg generation, thus exerting an immunosuppressive effect. Therefore, we cannot neglect the potential role of the renal allograft microenvironment in $\mathrm{DC}_{\text {reg }}$ development, and we need to prepare $\mathrm{DC}_{\text {reg }}$ with high stability and chemotactic performance.

\section{The origin of $\mathrm{DC}_{\mathrm{reg}}$ and induction method selection}

The team of Professor Li YP at Sichuan University of China conducted a meta-analysis of the effects of adoptively transferred $\mathrm{DC}_{\text {reg }}$ on renal allografts according to cell source, infusion route, mechanism and so on. They concluded that $\mathrm{DC}_{\text {reg }}$ derived from rat and mouse bone marrow precursor cells could induce immune tolerance in MHC-mismatched renal allografts and extend survival time; the effects of tolerance induction by immature DCs and genetically modified $\mathrm{DC}_{\text {reg }}$ were not significant [50]. The consulted references were all reports on rodent $\mathrm{KTx}$, and the $\mathrm{DC}_{\text {reg }}$ were derived from unrelated individuals; thus, the authors did not refer to the origin of the $\mathrm{DC}_{\text {reg }}$. However, the obtained results are of great significance for reference [51]. To enhance the specificity of $\mathrm{DC}_{\mathrm{reg}}$ the study gradually shifted to performing $\mathrm{KT}_{\mathrm{x}}$ in larger animals, and bone marrow precursor cells or peripheral blood mononuclear cells were collected from donors or recipients to induce $\mathrm{DC}_{\text {reg }}$.

Professor Thomas AW and his team completed a series of studies. They carried out rhesus monkey $\mathrm{KT}_{\mathrm{x}}$ and cell therapy with $\mathrm{DC}_{\text {reg }}$. In their studies, $\mathrm{DC}_{\text {reg }}$ were induced from donor peripheral blood mononuclear cells with vitamin D3 and IL-10 in combination with GM-CSF and IL-4. During the course of cell therapy, 8 weeks of CTLA4-Ig administration and 6 months of rapamycin treatment were continued. The results showed that $\mathrm{DC}_{\text {reg }}$ significantly prolonged the survival of renal allografts [52]. Further analysis indicated that the function of $\mathrm{DC}_{\text {reg }}$ was associated with downregulation of Emos transcript levels and upregulation of CTLA4 expression in donor responsive CD8+ memory $\mathrm{T}$ cells [53]. Infusion of $\mathrm{DC}_{\text {reg }}$ before transplantation sustained a high frequency of CD4+CTLA4hi T cells after transplantation, even if CD28 costimulatory signaling was blocked [54]. The authors obtained enhanced immunosuppressive effects with combined usage of donor antigen-loaded autologousderived $\mathrm{DC}_{\text {reg }}$ and low-dose immunosuppressants [55]. Their research results indicate the great potential of $\mathrm{DC}_{\text {reg }}$ application in organ transplantation recipients [56-58]. Now, their team is recruiting volunteers for phase I clinical trials of a $\mathrm{DC}_{\text {reg }}$-based cell therapy, and they plan to apply donor-derived $\mathrm{DC}_{\text {reg }}$ induced with vitamin D3 and IL-10. Another team that carried out an in-depth study of $\mathrm{DC}_{\text {reg }}$ is Professor Cuturi $\mathrm{MC}^{\text {'s }}$ team at Nantes University of France $[59,60]$. In the clinical trial "The One Study", they adoptively transferred autologous $\mathrm{DC}_{\text {reg }}$ pulsed with low-dose GM-CSF to treat living KTx recipients only once before surgery. Although no report has been published, the authors reported that no signs of rejection were observed after immunosuppressant withdrawal [61]. In these clinical trials, conventional induction methods were applied, and clinical effects remain to be reported. With developments in structural biology, pharmacology, genomics, immunology and other related disciplines, new induction methods are being developed to improve the performance and stability of $\mathrm{DC}_{\text {reg }}$.

\section{Conclusion}

It has been accepted that adoptive transfer of $\mathrm{DC}_{\text {reg }}$ should have good clinical application prospects given capability of these $\mathrm{DC}_{\mathrm{s}}$ to protect allografts [62]. We need to establish a treatment plan that can be referred to before clinical usage [63]. For solid organ transplantation, such as $\mathrm{KT}_{\mathrm{x}}$, the characteristics of kidney immunology and immunosuppressive regimens should be considered during the preparation of $\mathrm{DC}_{\text {reg }}$. Furthermore, the development of sensitive, safe and effective immunosurveillance markers is also a priority.

\section{Acknowledgments}

The authors gratefully acknowledge financial support from the 15th batch of the "six talent peaks" project in Jiangsu Province and the Science and Technology Project of the Changzhou Health Committee of Jiangsu Province (ZD201761).

\section{Conflict of Interest}

None.

\section{References}

1. Lim MA, Kohli J, Bloom RD (2017) Immunosuppresion for kidney transplantation: where are we now and where are we going? Transplant. Rev (Orlando) 31(1): 10-17.

2. Waisman A, Lukas D, Clausen BE, Yogev N (2017) Dendritic cells as gatekeepers of tolerance. Semin Immunopathol. 39(2):153-163.

3. Steptoe RJ, Thomson AW (1996) Dendritic cells and tolerance induction. Clin Exp Immunol 105(3): 397-402.

4. Ten Brinke, Martinez-Llordella M, Cool N, Hilkens CMU, van Ham SM, et al. (2019) Ways forward for tolerance-inducing cellular therapies- an AFACTT perspective. Front Immuol 10: 181. 
5. Anjuere F, Martin P, Ferrero I, Fraga ML, del Hovo GM, et al. (1999) Definition of dendritic cells subpopulations present in the spleen Peyer's patches, lymph nodes, and skin of the mouse. Blood 93(2): 590-598.

6. Xu H, Ma X, Song D, Xue D, He X, e al. (2016) Comparison of tolerogenic dendritic cells induced by liver $\mathrm{X}$ receptor agonist from bone marrowderived cells and natural tolerogenic dendritic cells. Clin Lab 62(3): 249261.

7. Nikolic T, Roep BO (2013) Regulatory multitasking of tolerogenic dendritic cells - lessons taken from vitamin d3-treated tolerogenic dendritic cells. Front Immunol 4: 113.

8. Bahri R, Naji A, Menier C, Charpentier B, Carosella ED, et al. (2009) Dendritic cells secrete the immunosuppressive HLA-G molecule upon CTLA4-Ig treatment: implication in human renal transplant acceptance. J Immunol 183(11): 7054-7062.

9. Hobo W, Maas F, Adisty N, de Witte T, Schaap N, et al. (2010) siRNA silencing of PD-L1 and PD-L2 on dendritic cells augments expansion and function of minor histocompatibility antigen-specific CD8+ T cells. Blood 116(22): 4501-4511.

10. Ye Y, Yan S, Jiang G, Zhou L, Xie H, et al. (2013) Galectin-1 prolongs survival of mouse liver allografts from Flt3L-pretreated donors. Am J Transplant 13(3): 569-579.

11. Zahorchak AF, Macedo C, Hamm DE, Butterfield LH, Metes DM, et al. (2018) High PD-L1/CD86 MFI ratio and IL-10 secretion characterize human regulatory dendritic cells generated for clinical testing in organ transplantation. Cell Immunol 323: 9-18.

12. Chu CC, Ali N, Karagiannis P, Meglio P, Skowera A, et al. (2012) Residen CD141 (BDCA3)+ dendritic cells in human skin produce IL-10 and induce regulatory $\mathrm{T}$ cells that suppress skin inflammation. J Exp Med 209(5): 935-945

13. Daniel V, Naujokat C, Sadeghi M, Wiesel M, Hergesell O, et al. (2005) Association of circulating interleukin (IL)-12- and IL-10-producing dendritic cells with time posttransplant, dose of immunosuppression, and plasma cytokines in renal-transplant recipients. Transplantation 79(11): 1498-1506.

14. Comi M, Amodio G, Gregori S (2018) Interleukin-10-producing DC-10 is a unique tool to promote tolerance via antigen-specific T regulatory type 1 cells. Front Immunol 9: 682.

15. Solva Pde M, Bier J, Paoatto LN, Galdino Albuquerque C, Lopes Souza C, et al. (2015) Tolerogenic dendritic cells on transplantation: immunotherapy based on second signal blockage. J Immunol Res 2015: 856707.

16. Horton C, Shanmugarajah K, Fairchild PJ (2017) Harnessing the properties of dendritic cells in the pursuit of immunological tolerance. Biomed J 40(2): 80-93.

17. Iberg CA, Jones A, Hawiger D (2017) Dendritic cells as inducers of peripheral tolerance. Trends Immunol 38(11): 793-804

18. Vlad G, Suciu-Foca N (2013) Tolerogenic dendritic cells and induction of T suppressor cells in transplant recipients. Methods Mol Biol 1034: 359-371.

19. Anderson AE, Swan DJ, Wong OY, Buck M, Eltherington O, et al. (2017) Tolerogenic dendritic cells generated with dexamethasone and vitamin D3 regulate rheumatoid arthritis CD4+ T cells partly via transforming growth factor- $\beta 1$. Clin Exp Immunol 187(1): 113-123.

20. Boks MA, Kager-Groenland JR, Haasjes MS, Zwaginga JJ, van Ham SM, et al. (2012) IL-10-generated tolerogenic dendritic cells are optimal for functional regulatory $\mathrm{T}$ cell induction-a comparative study of human clinical-applicable DC. Clin Immunol 142(3): 332-342.

21. Kryczanowsky F, Raker V, Graulich E, Domogalla MP, Steinbrink K (2016) IL-10-modulated human dendritic cells for clinical use: identification of a stable and migratory subset with improved tolerogenic activity. J Immunol 197(9): 3607-3617.

22. Na N, Luo Y, Zhao D, Yang S, Hong L, et al. (2016) Prolongation of kidney allograft survival regulated by indoleamine 2,3-dioxygenase in immature dendritic cells generated from recipient type bone marrow progenitors. Mol Immunol 79: 22-31.

23. Cook CH, Bickerstaff AA, Wang JJ, Nadasdy T, Della Pelle P, et al. (2008) Spontaneous renal allograft acceptance associated with "regulatory" dendritic cells and IDO. J Immunol 180 (5): 3103-3112.

24. Sun X, Gong ZJ, Wang ZW, Li T, Zhang JY, et al. (2012) IDO-competent-DCs induced by IFN $\gamma$ attenuate acute rejection in rat liver transplantation. J Clin Immunol 32(4): 837-847.

25. Hill M, Thebault P, Segovia M, Louvet C, Bériou G, et al. (2011) Cell therapy with autologous tolerogenic dendritic cells induces allograft tolerance through interferon-gamma and epstein-barr virus-induced gene 3. Am J Transplant 11(10): 2036-2045.

26. Pedersen AW, Claesson MH, Zocca MB (2011) Dendritic cells modified by vitamin D: future immunotherapy for autoimmune disease. Vitam Horm 86: 63-82.

27. Miyajima M, Chase CM, Alessandrini A, Farkash EA, Della Pelle P, et al. (2011) Early acceptance of renal allografts in mice is dependent on foxp3(+) cells. Am J Pathol 178(4): 1635-1645.

28. Hesselink DA, Vaessen LM, Hop WC, Schoordijk W, Ijzermans JN, et al. (2005) The effects of renal transplantation on circulating dendritic cells Clin Exp Immunol 140(2): 384-393.

29. Fangmann J, Wegmann C, Hoppe A, Martin P, Sack U, et al. (2007) Characterization of dendritic cell subsets in patients undergoing renal transplantation. Transplant Proc 39(10): 3101-3104.

30. Ma L, Liu Y, Wu J, Xu X, Liu F, et al. (2014) Changes in dendritic cells and dendritic cell subpopulations in peripheral blood of recipients during acute rejection after kidney transplantation. Chin Med J (Engl) 127(8): 1469-1473.

31. Hackstein H, Renner FC, Bohnert A, Nockher A, Frommer T, et al. (2005) Dendritic cell deficiency in the blood of kidney transplant patients on long-term immunosuppression: long-term immunosuppression: results of a prospective matched-cohort study. Am J Transplant 5(12): 29452953.

32. Sebelin K, Schulzki A, Kloetzel PM, Dörken B, Pezzutto A, et al. (2006) Impairment of circulating myeloid dendritic cells in immunosuppressed renal/pancreas transplant recipients. Transplantation 82(6): 77797787.

33. Stallone G, Pontrelli P, Infante B, Gigante M, Netti GS, et al. (2014) Rapamycin induces ILT3(high)ILT4(high) dendritic cells promoting a new immunoregulatory pathway. Kidney Int 85(4): 888-897.

34. Kirsch BM, Haidinger M, Zeyda M, Böhmig GA, Tombinsky J, et al. (2006) Alemtuzumab (Campath-1H) induction therapy and dendritic cells: Impact on peripheral dendritic cell repertoire in renal allograft recipients. Transpl Immunol 16(3-4): 254-257.

35. Bahri R, Naji A, Menier C, Charpentier B, Carosella ED, et al. (2009) Dendritic cells secrete the immunosuppressive HLA-G molecule upon CTLA4-Ig treatment: implication in human renal transplant acceptance. J Immunol 183(11): 7054-7062.

36. Furuzawa-Carballeda J, Uribe-Uribe NO, Arreola-Guerra JM, ReyesAcevedo R, Vilatobá M, et al. (2019) Tissue talks: immunophenotype of cells infiltrating the graft explains histological findings and the benefits of belatacept at 10 years. Clin Exp Immunol 197(2): 250-261.

37. Ueno T, Kim P, McGrath MM, Yeung MY, Shimizu T, et al. (2016) Live Images of Donor Dendritic Cells Trafficking via CX3CR1 Pathway. Front Immunol 7: 412.

38. Podestà MA, Cucchiari D, Ponticelli C (2015) The diverging role of the dendritic cells in kidney allotransplantation. Transplant Rev (Orlando) 29(3): 114-120.

39. Dai H, Thomson AW, Rogers NM (2019) Dendritic cells as sensors, mediators, and regulators of ischemic injury. Front Immunol 10: 2418. 
40. Zhuang Q Liu Q Divito SJ, Zeng Q, Yatim KM, et al. (2016) Graft-infiltrating host dendritic cells play a key role in organ transplant rejection. Nat Commun 7: 12623.

41. Batal I, De Serres SA, Safa K, Bijol V, Ueno T, et al. (2015) Dendritic cells in kidney transplant biopsy samples are associated with $\mathrm{T}$ cell infiltration and poor allograft survival. J Am Soc Nephrol 26(12): 3102-3113.

42. Hughes AD, Lakkis FG, Oberbarnscheidt MH (2018) Four-dimensional imaging of T cells in kidney transplant rejection. JAM Soc Nephrol 29(6): 1596-1600.

43. Woltman AM, de Fijter JW, van der Kooij SW, Jie KE, Massacrier C, et al. (2005) MIP-3alpha/CCL20 in renal transplantation and its possible involvement as dendritic cell chemoattractant in allograft rejection. Am J Transplant 5(9): 2114-2125.

44. Ruben JM, García-Romo GS, Breman E, van der Kooij S, Redeker A, et al. (2018) Human plasmacytoid dendritic cells acquire phagocytic capacity by TLR9 ligation in the presence of soluble factors produced by renal epithelial cells. Kidney Int 93(2): 355-364.

45. Rogers NM, Isenberg JS, Thomson AW (2013) Plasmacytoid dendritic cells: no longer an enigma and now key to transplant tolerance? Am J Transplant 13(5): 1125-1133.

46. Tung SL, Boardman DA, Sen M, Letizia M, Peng Q et al. (2018) Regulatory T cell-derived extracellular vesicles modify dendritic cell function. Sci Rep 8(1): 6065

47. Chessa F, Mathow D, Wang S, Hielscher T, Atzberger A, et al. (2016) The renal microenvironment modifies dendritic cell phenotype. Kidney Int 89(1): 82-94.

48. Jobin K, Heuser C, Kurts C (2016) A grain of salt on kidney dendritic cell function in allograft rejection. Kidney Int 89(1): 14-16.

49. Heidkamp GF, Sander J, Lehmann CHK, Heger L, Eissing N, et al. (2016) Human lymphoid organ dendritic cell identity is predominantly dictated by ontogeny, not tissue microenvironment. Sci Immunol 1(6): eaai7677.

50. Xia MJ, Shan J, Li YP, Zhou YN, Guo YJ, et al. (2013) Adoptive transfusion of tolerant dendritic cells prolong the survival of renal allografts: a systemiatic. J Evid Based Med 6(4): 250-264.

51. Raïch-Regué D, Glancy M, Thomson AW (2014) Regulatory dendritic cells therapy: from rodents to clinical application. Immunol Lett 161(2): 216-221.

52. Ezzelarab MB, Zahorchak AF, Lu L, Morelli AE, Chalasani G, et al. (2013) Regulatory dendritic cell infusion prolongs allograft survival in nonhuman primates. Am J Transplant 13(8): 1989-2005.

53. Ezzelarab MB, Lu L, Guo H, Zahorchak AF, Shufesky WF, et al. (2016) Eomesodermin(lo) CTLA4(hi) Alloreactive CD8+ Memory T Cells Are Associated with Prolonged Renal Transplant Survival Induced by Regulatory Dendritic Cell Infusion in CTLA4 Immunoglobulin-Treated Nonhuman Primates. Transplantation 100(1): 91-102.

54. Ezzelarab MB, Lu L, Shufesky WF, Morelli AE, Thomson AW (2018) Donor-Derived Regulatory Dendritic Cell Infusion Maintains DonorReactive CD4+CTLA4hi T Cells in Non-Human Primate Renal Allograft Recipients Treated with CD28 Co-Stimulation Blockade. Front Immunol 9: 250 .

55. Ezzelarab MB, Raich-Regue D, Lu L, Zahorchak AF, Perez-Gutierrez A et al. (2017) Renal Allograft Survival in Nonhuman Primates Infused with Donor Antigen-Pulsed Autologous Regulatory Dendritic Cells. Am J Transplant 17(6): 1476-1489.

56. Thomson AW, Zahorchak AF, Ezzelarab MB, Butterfield LH, Lakkis FG, et al. (2016) Prospecctive clinical testing of regulatory dendritic cells in organ transplantation. Front Immunol 7: 15.

57. Thomson AW, Ezzelarab MB (2018) Regulatory dendritic cells: profiling, targeting, and therapeutic application. Curr Opin Organ Transplant 23(5): 538-545.

58. Thomson AW, Metes DM, Ezzelarab MB, Raïch-Regué D (2019) Regulatory dendritic cells for human organ transplantation. Transplant Rev (Orlando) 33(3): 130-136.

59. Moreau A, Varey E, Bouchet-Delbos L, Cuturi MC (2012) Cell therapy using tolerogenic dendritic cells in transplantation. Transplant Res 1(1): 13.

60. Moreau A, Varey E, Bériou G, Hill M, Bouchet-Delbos L, et al. (2012) Tolerogenic dendritic cells and negative vaccination in transplantation: from rodents to clinical trials. Front Immunol 3: 218.

61. Kawai T, Leventhal J, Wood K, Strober S (2019) Summary of the Third International Workshop on clinical tolerance. Am J Transplant 19(2): 324-330.

62. Li H, Shi B (2015) Tolerogenic dendritic cells and their applications in transplantation. Cell Mol Immunol 12(1): 24-30.

63. Zhou Y, Shan J, Guo Y, Li S, Long D, et al. (2016) Effects of adoptive transfer of tolerogenic dendritic cells on allograft survival in organ transplantation models: an overview of systematic reviews. J Immunol Res 2016: 5730674 